\title{
Influence of avoparcin on rabbit performances
}

\author{
M. BOUGON, J. P. MORISSE et R. L'HOSPITALIER \\ Station expérimentale d'Aviculture, B.P. 9, 22+to Ploulvagan (France)
}

\begin{abstract}
Aroparcin is a new glycoprotein antibiotic produced by fermentation of a strain of Streptomyces candidus.

Its efficiency as a feed additive was studied in 08 rabbits, divided into 3 treatments (diets $\mathrm{A}$, $B$ and $C$ ).

Diet A was the control feed without Avoparcin.

Diet $B$ and $C$ were the sante as the control feed but admixed with ro and 20 ppm Avoparcin, respectively.

At the age of 50 days, the average weight of the rabbits was :
Diet A: I $72 \mathrm{Ig}$
Diet B : I $803 \mathrm{~g}$
Diet C : I $770 \mathrm{~g}$

It increased and was the following at the age of 65 days:

$$
\text { Diet A : } 2197 \mathrm{~g} \text { Diet } \mathrm{B}: 2280 \mathrm{~g} \text { Diet C : } 22 \mathrm{IIg}
$$

The incorporation of $10 \mathrm{ppm}$ Avoparcin into the diet led to a $6.4 \mathrm{p}$. I 00 weight gain in the rabbits, between 30 and 65 days, without changing the feed conversion ratio.

Use of $20 \mathrm{ppm}$ Avoparcin in the diet was of little interest : the weight gain of the rabbits increased only by I.2 $_{2}$ p. 100 between 30 to 65 days, and the feed conversion ratio increased by + p. Ioo.

The effect of Avoparcin on growth was more marked in the males than in the females. Addition of the antibiotic to the diet did not affect either the mortality rate or the dressing percentage.
\end{abstract}

III. - GROWTH AND BODY COMPOSITION

\section{Growth and feed intake according to age studied in a strain of rabbits}

\author{
R. HENAFF, G. PERRIER(*) \\ Chaive de Zootechnie, E.N.F.A. de Clermond-Ferrand, \\ 63370 Lempdes (France) \\ (*) Chaive de production animale, E.N.I.T.A. de Lijon \\ 2 I80o Quetigny (France)
}

(irowth and feed intake in a strain of crossbred rabbits New Zealand white $C$ Californian $\times$ small Russian $\times$ meat line were studied each week between the age of 35 and $9 \mathrm{I}$ days.

The growth rate tended to increase from the initial period, $35-42 \mathrm{~d},(36.5 \mathrm{~g} / \mathrm{d})$ till $63-7 \mathrm{o} \mathrm{d}$ $(40.7 \mathrm{~g} / \mathrm{d})$. Then it rapidly decreased and reached $29.8 \mathrm{~g} / \mathrm{d}$ between 84 and $9 \mathrm{r}$ davs. The feed conversion ratio increased permanently, but accelerated fastly after 84 days. For the above mentioned reference periods, it was 1.97 between 35 and 42 days, 3.20 between 63 and $70 \mathrm{~d}$ and 5.10 between 84 and 91 days.

As compared to the dry matter intake, the variation in the water intake according to time was not significant. The ratio water/dry matter remained constant : I.9 \pm 0.2 .

For the whole experimental period, the water intake was $90 \pm 0.01 \mathrm{~g} /$ day and per $\mathrm{kg}$ metabolic weight $\left(\mathrm{W}^{0.66}\right)$. 